\title{
PENDAYAGUNAAN LINGKUNGAN \\ BAGI PEMBERDAYAAN MASYARAKAT
}

\section{Oleh: Epon Ningrum*)}

\begin{abstract}
ABSTRAK
Pada hakikatnya, kolektivitas manusia yang memiliki tata aturan relatif permanen berada pada tiga tatanan lingkungan, yakni lingkungan: sosial, budaya, dan alam (fisis geografis). Ketiga tatanan lingkungan tersebut merupakan potensi bagi kelangsungan (survive) dan kemajuan masyarakat. Lingkungan terdiri atas komponen biotik dan abiotik, yang dapat didayagunakan bagi pemberdayaan masyarakat. Untuk itu, diperlukan upaya transformasi potensi lingkungan ke dalam keuntungan sosial dan kultural.

Dinamika demografis menuntut intensitas tranfer dan eksploitasi sumber daya lingkungan bagi terpenuhinya kebutuhan masyarakat. Kondisi demikian dapat menganggu keberadaan lingkungan, sehingga sangat penting upaya pemanfaatannya secara efektif dan efisien agar lingkungan berfungsi sebagai sumber kehidupan yang berkelanjutan bagi masyarakat. Teknologi yang dipandang efektif dan efisien serta memiliki daya suai dengan ketiga tatanan lingkungan adalah teknologi adaptif dan teknologi protektif.

Pemberdayaan masyarakat dengan mendayagunakan potensi lingkungan mengacu pada lima strategi, yakni: need oriented, endogenous, self-reliant, ecologically sound, dan based on structural transformations. Pada prinsipnya, konsep pemberdayaan memiliki makna yang sama dengan konsep pembangunan dan pengembangan, yakni bertujuan meningkatkan taraf kehidupan masyarakat. Berdasarkan kelima strategi tersebut, maka kebaradaan masayarakat dalam konteksitas lingkungannya akan tercapai kondisi: (1) masyarakat dan lingkungannya berada pada keseimbangan yang terlestarikan; (2) potensi lingkungan dapat teraktualisasikan; dan (3) lingkungan sebagai sumber kehidupan dan proses pemberdayaan masyarakat dapat berkelanjutan, sehinga pada jangka panjang akan tercapai kesejahteraan masyarakat.
\end{abstract}

Kata Kunci: Lingkungan, pemberdayaan, masyarakat, teknologi adaptif, teknologi protektif.

*) Dr. Epon Ningrum, M.Pd., adalah dosen Jurusan Pendidikan Geografi FPIPS UPI.

\section{Pendahuluan}


Lingkungan dan masyarakat adalah dua konsep yang memiliki keterkaitan secara fungsional dalam konteks ekologi dan ekosistem. Berdasarkan sudut pandang (view point) yang berbeda, telaah empiris telah menghasilkan suatu sintesa tentang hubungan masyarakat dengan lingkungannya. Menurut kaum deterministis, lingkungan alam menentukan corak kehidupan masyarakat, kaum posibilistik memandang lingkungan sebagai faktor yang berpengaruh, sedangkan kaum optimistik teknologi memiliki keyakinan akan keampuhan IPTEK untuk mendayagunakan potensi lingkungan.

Berdasarkan ketiga pandangan tersebut, maka keberadaan masyarakat dalam lingkungannya bergantung pada tingkat kemampuan yang dimilikinya. Secara konsepsional bahwa manusia merupakan faktor dominant terhadap lingkungannya (man ecological dominant concept) telah menampakkan fenomena kehidupan masyarakat yang variatif dan disparitas antar wilayah dan antar masyarakat. Beragamnya aktivitas, perbedaan tingkat kesejahteraan, dan dinamika perubahan masyarakat adalah merupakan konsekuensi logis dari konsep tersebut.

Masyarakat dengan aktivitasnya menjadi fenomena yang memberikan warna dominan terhadap suatu ruang geografis. Di mana, aktivitas masyarakat tersebut pada hakikatnya adalah merupakan respons terhadap stimulus yang berasal dari lingkungannya. Manusia sebagai individu dalam kolektifitasnya membentuk tatanan kehidupan bermasyarakat. Menurut Sumaatmadja (1996:15), manusia sebagai mahluk hidup berada di tengah-tengah manusia lainnya (lingkungan sosial), dalam konteks budaya (lingkungan budaya), dan alam semesta (lingkungan alam). Ketiga lingkungan tersebut merupakan tiga faktor yang memiliki jalinan hubungan secara fungsional. Adimihardja (1993:1) mengemukakan bahwa manusia, kebudayaan, dan lingkungan merupakan tiga faktor yang saling jalin menjalin secara integral.

Keberadaan masyarakat dengan lingkungannya merupakan satu kesatuan yang utuh. Namun demikian, keberadaan masyarakat dengan kebudayaannya telah banyak turut serta mempengaruhi kondisi lingkungan hidup. Bagaimanakah menjaga keutuhan hubungan masyarakat dengan lingkungannya dan terjaganya keseimbangan sehingga lingkungan menjadi sumber kelangsungan hidup masyarakat secara berkelanjutan.

\section{Transfer Potensi Lingkungan ke dalam Keuntungan Sosial dan Kultural}

Manusia memiliki banyak predikat yang melekat pada dirinya, ia sebagai individu sebagai mahluk sosial dan berbudaya serta khalifah di muka bumi. Secara hahiki, manusia sebagai mahluk Tuhan yang harus mempertanggungjawabkan perbuatannya, baik terhadap sesama manusia maupun lingkungannya. Manusia sebagai individu memiliki otonomi atas dirinya. Namun demikian, sebagai mahluk sosial otoritas dirinya terbatasi oleh norma dan nilai sosial, hingga ia bisa hidup bermasyarakat yang menjadi wahana bagi kelangsungan kehidupannya.

Masyarakat adalah kesatuan hidup manusia yang berinteraksi menurut suatu sistem adat tertentu yang bersifat kontinyu dan terikat oleh suatu rasa identitas bersama (Koentjaraningrat, 1980:160). Kolektivitas kehidupan manusia 
yang berwujud masyarakat tersebut menjadi wahana bagi pengembangan diri dan menjadi sumber daya bagi kemajuan masyarakatnya. Dinamika kehidupan masyarakat dipengaruhi oleh banyak faktor, baik yang bersifat sosial budaya maupun fisis geografis. Dengan demikian, secara faktual empiris dapat ditemui adanya perbedaan tingkat perkembangan kemajuan masyarakat.

Manusia sebagai mahluk sosial dalam lingkungan hidupnya memiliki dominasi yang kuat terutama dalam pengelolaan sumber-sumber kehidupan. Dominasi tersebut sangat ditentungan oleh ilmu pengetahuan dan teknologi yang dimiliki oleh masyarakat. Lingkungan menjadi ruang hidup bagi masyarakat manakala lingkungan tersebut memiliki potensi dan masyarakat memiliki kemampuan untuk mendayagunakannya bagi kelangsungan kehidupan mereka. Konsep life layer yang dikemukakan oleh Henry J. Warman (Gabler, 1969:13) memberikan ilustrasi kepada kita bahwa tidak seluruh permukaan bumi menjadi ruang hidup, melainkan hanya ruang potensial yang akan dijadikan tempat tinggal manusia. Keberadaan lingkungan sebagai ruang hidup masyarakat akan terlestarikan jika manusia penghuninya memiliki kepedulian dan rasa tanggung jawab pewarisan kepada generasi beikutnya.

Secara umum, lingkungan terdiri atas dua komponen yaitu komponen biotik dan komponen abiotik. Kedua komponen tersebut merupakan potensi lingkungan yang menjadi sumber kehidupan masyarakat. Komponen biotik terdiri atas mahluk hidup dan mahluk hidup yang berperan dominan adalah manusia serta kelembagaan sosial. Sedangkan komponen abiotik adalah keseluruhan benda mati, baik alamiah maupun hasil rekayasa manusia. Setiap komponen memiliki fungsi masing-masing secara solid sehingga membentuk lingkungan hidup. Sedangkan dalam konteksitas manusia, lingkungan terdiri atas lingkungan sosial, lingkungan budaya, dan lingkungan alam. Ilustrasi pada gambar 1 merupakan gambaran tentang lingkungan beserta komponen-komponennya yang bersifat potensial.

Potensi lingkungan menjadi sumber daya bagi kelangsungan hidup masyarakat karena dari lingkungan masyarakat mendapatkan unsur-unsur yang diperlukannya untuk produksi dan konsumsi. Sumber daya tersebut akan berdaya guna manakala masyarakat tersebut memiliki ilmu pengetahuan dan teknologi bagi pengelolaannya. Soemarwoto (1983:66) mengartikan pengelolaan lingkungan sebagai usaha secara sadar untuk memelihara atau memperbaiki mutu lingkungan agar kebutuhan hidup dapat terpenuhi dengan sebaik-baiknya.

Hal yang perlu disadari bahwa faktor lingkungan bersifat mendukung (diving force) dan menghambat (restraining force) dinamika kehidupan masyarakat. Faktor lingkungan yang bersifat mendukung merupakan potensi yang dapat didayagunakan.. Menurut Soemarwoto (1983:61), faktor lingkungan yang mendukung merupakan manfaat lingkungan, sedangkan yang merintangi merupakan risiko lingkungan.

Faktor lingkungan yang mendukung dan menghambat bersifat relatif bagi masyarakat, akan tetapi keduanya menjadi motor penggerak muncul dan berkembangnya teknologi. Teknologi merupakan hasil rekayasa manusia dalam tatanan hidup bermasyarakat (individu in society). Dalam perkembangannya, teknologi dipengaruhi oleh dua faktor yakni: (1) faktor yang berasal dari masyarakat berupa tuntutan untuk terpenuhinya kebutuhan hidup; dan (2) faktor 
yang datangnya dari luar masyarakat baik yang sifatnya fisik alamiah maupun pengaruh masyarakat lain.

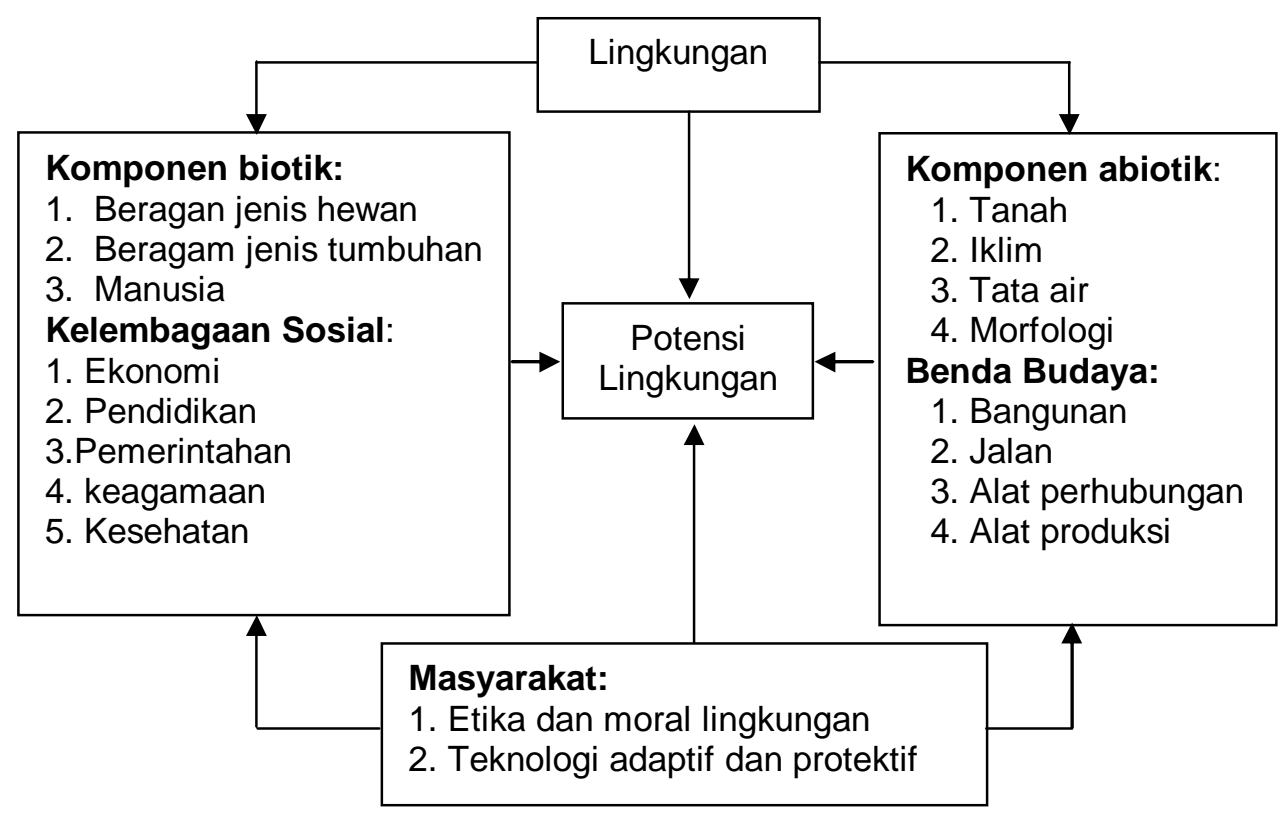

Gambar 1: Komponen lingkungan yang menjadi potensi

bagi kehidupan masyarakat

Namun, disinyalir banyak para ilmuwan bahwa keberadaan masyarakat dan penggunaan teknologi dalam pemanfaatan potensi lingkungan adalah aspek yang merusak tata lingkungan dan pembawa bencana. Sejalan dengan dinamika demografis dan bentuk aktivitasnya maka pemanfaatan potensi lingkungan semakin meningkat pula jumlah dan bentuk serta intensitasnya. Kondisi ini telah melahirkan suatu peramalan dari para pemerhati lingkungan bahwa kekeradaan lingkungan sebagai sumber kehidupan masyarakat memiliki keterbatasan (limits to growth).

Pemikiran Zimmermann (Hunker, 1964:7) sangat bijak dalam memandang hubungan masyarakat dengan lingkungannya, bahwa kearifan dan akal budi manusia pada akhirnya dapat menjadi sumber daya utama. Untuk itu, diperlukan upaya pengambangan sumber daya manusia (human resources development) yang berorientasi pada terwujudnya masayarakat yang memiliki kearifan, akal budi, dan beretika serta bermoral lingkungan. Keberadaan masyarakat dalam tatanan lingkungannya akan menunjukkan hubungan yang sinergis jika mereka berperilaku, berinteraksi, dan beradaptasi serta memanfaatkan sumber-sumber kehidupan berpola pada etika lingkungan, sehingga akan melahirkan moral lingkungan yang secara signifikan berpengaruh terhadap kelestarian lingkungan secara berkelanjutan. 
Pemanfaatan sumber-sumber tersebut tidak terlepas dari konsep teknologi. Teknologi yang memiliki daya suai dengan potensi lingkungan dan ikutserta melestarikan keberadaannya bagi kelangsungan hidup masyarakat adalah teknologi yang bersifat adaptif dan protektif. Menurut Zen (1984: 102-102), teknolodi adaptif atau disebut teknologi madya yaitu teknologi yang disesuaikan dan diserasikan dengan pertimbangan-pertimbangan keadaan lingkungan di masyarakat. Sedangkan teknologi protektif adalah teknologi yang bersifat memelihara, melindungi, dan mengamankan ekosistem dengan berasaskan pada aspek konservasi, restorasi, dan re-generasi segenap sumber daya lingkungan yang berada dalam masyarakat.

Teknologi adaptif dan protektif menjadi salah satu alternatif untuk mentransfer potensi lingkungan ke dalam keuntungan sosial dan kultural serta terlestarikannya sumber-sumber kehidupan masyarakat. Pendayagunaan potensi tersebut diperlukan kearifan berfikir dan bertindak agar lingkungan hidup memberikan sumber-sumber kehidupan secara berkelanjutan. Dengan demikian, penggunaan teknologi adaptif dan protektif dalam mendayagunakan potensi lingkungan menjadi pilihan yang strategis.

\section{Strategi Pemberdayaan Masyarakat dalam Tatanan Lingkungan}

Pemberdayaan masyarakat adalah suatu proses aktualisasi potensi yang terdapat di lingkungan masyarakat, baik potensi sosial dan budaya maupun fisis geografis. Suzanne Kindevatter (1979:13) mengemukakan bahwa: "empowering is people gaining an understanding of and control over social, economic, and/or political proces in order to improve their standing in society". Pemberdayaan sebagai proses pemberian kekuatan pada masyarakat agar memiliki kepekaan terhadap perkembangan sosial, ekonomi, dan politik sehingga mereka memiliki keinginan dan kemampuan untuk memperbaiki dan meningkatkan posisinya.

Suatu aktivitas masyarakat dikatakan pemberdayaan manakala memiliki empat karakteristik, yaitu; (1) community organization; (2) worker selfmanagement and collaboration; (3) participatory approach; dan (4) education for justice. Berdasarkan keempat karakteristik pemberdayaan tersebut, masyarakat akan memiliki kesadaran, keinginan, dan kemampuan dalam meningkatkan taraf kehidupannya. Kesadaran masyarakat akan mendorong untuk bersikap responsif terhdap suatu peristiwa, baik yang terjadi di dalam maupun di luar masyarakat, baik peristiwa sosial dan budaya maupun gejala alam. Keinginan masyarakat merupakan kekuatan motivasional secara intrinsik yang menjadi motor penggerak daya juang masyarakat. Kemampuan masyarakat bersumber dari potensi lingkungn yakni potensi sosial dan budaya serta fisis geografis, yang dapat diberdayakan, sehingga keberdayaan mereka dapat berkelanjutan.

Selanjutnya Suzanne Kindevatter (1979:46) memberikan arahan tentang strategi dan prinsip-prinsip pemberdayaan, yakni: (1) need oriented; (2) endogenous; (3) self-reliant; (4) ecologically sound; dan (5) based on structural transformations. Dalam upaya pemberdayaan masyarakat, masyarakat menjadi titik sentral atau dengan kata lain dari-oleh- dan untuk masyarakat.

Berdasarkan kelima strategi pemberdayaan masyarakat tersebut dalam konteksitas pendayagunaan potensi lingkungan, maka: (1) Kebutuhan masyarakat menjadi kunci utama (starting point) dalam proses pemberdayaan; (2) Lingkungan 
bagi masyarakat merupakan potensi lokalit untuk didayagunakan, sehingga dapat melahirkan rasa tanggung jawab (sense of responsibility) dalam memelihara kelestariannya; (3) Upaya pemberdayaan masyarakat adalah bertujuan untuk memenuhi kebutuhannya, manakala berhasil maka proses pemberdayaan akan berkelanjutan di laksanakan oleh masyarakat; (4) Komponen lingkungan adalah potensi yang dimiliki oleh masyarakat yang dapat didayagunakan dalam proses pemberdayaan masyarakat. Komponen biotic meliputi keanekaragam sumber daya hayati dan masyarakat beserta kelembagaannya. Sedangkan komponen abiotik meliputi sumber daya alam dan benda budaya; dan (5) Pemberdayaan masyarakat dapat menimbulkan perubahan secara structural kea rah yang lebih baik.

Joyomartono (1991:31) mengemukakan bahwa: "Pengembangan masyarakat adalah upaya merealisasikan potensi yang terdapat dalam masyarakat sehingga mampu memenuhi kebutuhan hidup, meningkatkan pengelolaan sumber daya alam dan sumber daya manusia, meningkatkan kemampuan menciptakan sarana hidup dalam bentuk ilmu pengetahuan dan teknologi serta penyesuaian tata kemasyarakatan dengan perubahan kehidupan sebagai kebudayaan. Penerimaan masyarakat terhadap inovasi merupakan langkah awal dan kunci keberhasilan pembangunan, sehingga akan terjadi perubahan masyarakat dalam aspek sosial, ekonomi, dan budaya ke arah yang lebih baik sebagai hasil pembangunan". Soemarwoto (1983:69) mengemukakan keterkaitan pembangunan masyarakat dengan lingkungan adalah sebagai perubahan lingkungan, yakni mengurangi risiko lingkungan atau dan memperbesar manfaat lingkungan.

Pengertian pemberdayaan dengan pengembangan memiliki makna yang sama yakni upaya peningkatan kesejahteraan masyarakat melalui pendayagunaan potensi lingkungan, sehingga dapat bermanfaat bagi kemajuannya. Konsep lain yang memiliki kesamaan makna adalah pembangunan. Fungsi utama pembangunan masyarakat adalah memperbaiki taraf dan kualitas kehidupan masyarakat. tinggi kemampuan semua sumber

Pembangunan masyarakat dipengaruhi oleh beberapa faktor, yakni faktor sosial budaya dan faktor fisis geografis. Faktor fisis geografis menyediakan sumber daya alam yang potensial sebagai sumber kehidupan bagi kesejahteraan manusia. Namun demikian, dalam pedayagunaan sumber-sumber bergantung pada kemampuan masyarakat. Sumaatmadja (1996:5) mengemukakan tentang pemanfaatan sumber daya alam dibatasi oleh budaya masyarakat (culturally defined resources). Faktor fisis geografis ada yang bersifat menunjang dan menghambat bagi peningkatan kesejahteraan masyarakat, di mana pendayagunaannya sangat bergantung pada tingkat pengetahuan dan teknologi yang dimiliki masyarakat. Salah satu peran geografi dalam pemberdayaan sumber daya wilayah adalah inventarisasi sumberdaya wilayah yang mencakup sumberdaya alam, sumber daya manusia, dan sumber daya binaan. Sumber daya manusia dan sumber daya binaan merupakan budaya masyarakat yang dapat mendayagunakan sumber daya alam.

Dalam upaya mempercepat proses pemberdayaan masyarakat diperlukan adanya intervensi dari pihak luar. Pada hakikatnya, intervensi terhadap masyarakat adalah memasukkan unsure baru (inovasi) ke dalam tatanan 
kehidupan masyarakat. Dengan adanya intervensi tersebut, maka kondisi lingkungan dan masyarakat akan mengalami ganggungan. Agar intervensi tersebut berlangsung efektif dan efisien, maka harus memiliki kesesuaian dengan kondisi dan karakteristik masyarakat sasaran. Hasil studi Ningrum (1996) menunjukkan bahwa pemanfaatan pohon bambo untuk usaha kerajinan telah meningkat pendapatan masyarakat Kampun Naga. Hal ini menunjukkan bahwa bentuk intervensi yang diberikan kepada masyarakat Kampung Naga memiliki dampak fungsional secara social dan tidak bertentangan dengan unsure budaya.

Diterimanya unsure baru oleh masyarakat tidak terlepas dari sifat inovasi. Untuk itu, Rogers (1983: 213-232) mengemukakan lima sifat inovasi agar mudah diadopsi, oleh masyarakat. Kelima karakteristik tersebut adalah: (1) relatif advantage; (2) compatibility; (3) complexity; (4) triability; dan (5) observability. Suatu inovasi akan relatif mudah diterima oleh masyarakat jika secara ekonomi menguntungkan, secara teknis mudah dilaksanakan, secara budaya tidak bertentangan dengan adat istiadat, secara praktis dapat dicoba, dan bersifat kasat mata. Masyarakat yang memiliki sikap terbuka terhadap unsur budaya luar cenderung memiliki tingkat dinamika tinggi dan proses transformasi sosial budaya relatif cepat.

Suatu inovasi yang dipandang memiliki daya suai (adaptabilitas) terhadap lingkungan, memiliki ketangguhan, dan ketahanan (homeostatik) bagi kelangsungan hidup bermasyarakat akan dilestarikan. Lingkungan, baik sosial dan budaya maupun fisis geografis secara potensial memiliki daya dukung bagi kehidupan masyarakat. Pemberdayaan masyarakat dapat berhasil dan prosesnya berkelanjutan manakal berada pada lingkungan yang memiliki daya dukung. Persayaratan utama yang harus dipenuhi adalah: (1) Masuknya unsure baru ke dalam tatanan kehidupan masyarakat tidak menyebabkan terganggunya proses ekologi dan kerusakan lingkungan; (2) Pendayagunaan potensi lingkungan secara secara efektif dan efisien, sehingga lingkungan menjadi sumber kehidupan yang berkelanjutan; dan (3) Masyarakat memiliki kepedulian dan tanggung jawab terhadap lingkungan.

\section{Penutup}

Masyarakat dalam tatanan lingkungannya memiliki potensi yang dapat didayagunakan bagi peningkatan kehidupannya. Pemanfatan potensi tersebut selain memerlukan IPTEK juga kearifan masyarakat terhadap lingkungan. Teknologi yang memiliki daya adaptabilitas terhadap lingkungan dan kelestariannya adalah teknologi adaptif dan teknologi protektif. Sedangkan kearifan terhadap lingkungan adalah perilaku masyarakat yang beretika dan bermoral lingkungan serta berorientasi ke masa depan. Konteksitas masyarakat dengan lingkungan adalah pendayagunaan potensi lingkungan bagi proses pemberdayaan masyarakat secara berkelanjutan. Strategi pemberdayaan masyarakat berorientasi lokalitas pada lingkungan sosial, lingkungan budaya, dan lingkungan fisi geografis. Intervensi yang adaptif terhadap masyarakat dan lingkungannya, selain dapat mempercepat proses pemberdayaan juga akan menjadi kekuatan motivasional (self-empowerment). 


\section{Daftar Pustaka}

Adimihardja, Kusnaka. 1993. Kebudayaan dan Lingkungan. Bandung: Ilham Jaya. Hunker, Henry, L. 1964. Zimmermann's Introdusction To World Resources. New York: Harper \& Row Publ.

Gabler, R.E. 1969. A HandbookFor Geography Teacher. Illinois; Publacation center Nation for Geographic Education.

Joyomartono, Mulyono. 1991. Perubahan Kebudayaan dan Masyarakat dalam Pembangunan. Semarang: IKIP Semarang.

Kindevater, Suzanne. 1977. Non Formal Education As An Empowering Process. Amhers: Center For International Education.

Koentjaraningrat. 1984. Kebudayaan, Mentalitas, dan Pembangunan. Jakarta: Gramedia

Miller, Jr., G.T. 1985. Living In The Environment. California: Wadsworth Publishing Company.

Ningrum, Epon. 1996. Pembelajaran Partisipatif sebagai Strategi Pemberdayaan dalam Pengembangan Sosial Ekonomi Masyarakat Kampung Naga. Tesis. Program Pascasarjana IKIP Bandung.

Rogers, Everett, M. 1983. Diffusion of Innovation. 3 ed. New York: The Free Press.

Soemarwoto, Otto. 1983. Ekologi Lingkungan Hidup dan Pembangunan. Jakarta: Djambatan.

Sumaatmadja, Nursid. 1996. Manusia dalam Konteks Sosial, Budaya dan Lingkungan Hidup. Bandung: Alfabeta.

Zen,M.T. 1984. Menuju Kelestarian Lingkungan Hidup. Jakarta: Gramedia. 